\title{
Monitoring and forecasting Etna volcanic plumes
}

\author{
S. Scollo, M. Prestifilippo, G. Spata, M. D'Agostino, and M. Coltelli \\ Istituto Nazionale di Geofisica e Vulcanologia, sezione di Catania, Catania, Italy \\ Received: 9 July 2009 - Accepted: 25 August 2009 - Published: 23 September 2009
}

\begin{abstract}
In this paper we describe the results of a project ongoing at the Istituto Nazionale di Geofisica e Vulcanologia (INGV). The objective is to develop and implement a system for monitoring and forecasting volcanic plumes of Etna. Monitoring is based at present by multispectral infrared measurements from the Spin Enhanced Visible and Infrared Imager on board the Meteosat Second Generation geosynchronous satellite, visual and thermal cameras, and three radar disdrometers able to detect ash dispersal and fallout. Forecasting is performed by using automatic procedures for: i) downloading weather forecast data from meteorological mesoscale models; ii) running models of tephra dispersal, iii) plotting hazard maps of volcanic ash dispersal and deposition for certain scenarios and, iv) publishing the results on a web-site dedicated to the Italian Civil Protection. Simulations are based on eruptive scenarios obtained by analysing field data collected after the end of recent Etna eruptions. Forecasting is, hence, supported by plume observations carried out by the monitoring system. The system was tested on some explosive events occurred during 2006 and 2007 successfully. The potentiality use of monitoring and forecasting Etna volcanic plumes, in a way to prevent threats to aviation from volcanic ash, is finally discussed.
\end{abstract}

\section{Introduction}

Volcanic ash causes damages to infrastructure and telecommunication, contamination of crops and water supply (Blong, 1984; Casadewall, 1994). It may create serious health problems such a respiratory diseases and illness (Horwell and Baxter, 2006) and is extremely dangerous for air traffic (Casadevall, 1994). Threats as ruin to windscreens, fuselage surfaces and landing lights are documented in detail (Miller and Casadevall, 2000; Guffanti and Miller, 2002; Salinas, 2004). The most dangerous threat is the engine total failure.

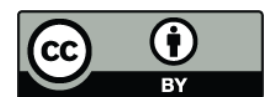

Correspondence to: S. Scollo (scollo@ct.ingv.it)
In fact, volcanic ash has a fusion temperature lower than modern jet engine operating temperatures, and consequently may melt in the hot section and re-solidify in the colder parts of the engine as nozzle guide vanes and turbine blades, causing the degraded engine performance (Guffanti et al., 2005). The first famous case of such accidents occurred on 24 June 1982 when a British Airways Flight 9, a Boeing 747-200 flying at an elevation of $11470 \mathrm{~m}$ from Kuala Lumpur, in Malaysia, to Perth, in Australia, encountered volcanic ash after passing over Krakatau volcano. All four engines failed but luckily, at about $3650 \mathrm{~m}$, the pilot was able to restart three engines and make an emergency landing at Jakarta, in Indonesia (ICAO, 2004).

One of the early reported incidents of an airport impacted by volcanic activity was during WWII, when the 1944 Vesuvius eruption destroyed 88 B-25 bombers of the US 340th Bombardment Group based in Naples. Another important effect of ash on aviation is the airport operation. Guffanti et al. (2004) reported 108 incidents since 1944 due to eruptions of 34 volcanoes that involved 75 airports. Tephra fallout causes in fact disruption due to slippery runways and reduced visibility, deposition of ash on parked planes and buildings, remobilization of deposited ash by machinery, aircraft, and wind, and contamination of various ground-support facilities, including ATC computer systems. Consequently, airports located near active volcanoes are often forced to close to prevent similar disasters.

In 1987, the International Civil Aviation Organization (ICAO) established the International Airways Volcano Watch (IAVW) commission that defines international protocols for the monitoring and provision of warnings to aircrafts in presence of volcanic ash in the atmosphere (Romero, 2004). Information on volcanic ash to aircraft is given through SIGMETs and NOTAMs issued by the Meteorological Watch Offices (MWOs) and Aeronautical Control Centres (ACCs) through their NOTAM Offices (NOFs) (Romero, 2004). To assist MWOs on drafting the SIGMETS nine volcanic ash advisory centres (VAACs) were established at Anchorage, Washington, Buenos Aires, Montreal, London, Toulouse, Tokyo, Darwin and Wellington with the aim to provide

Published by Copernicus Publications on behalf of the European Geosciences Union. 
advisories on the plume dispersal and act like an interface between MWOs, traffic control centres, and volcano observatories (Webley and Mastin, 2008). These are essential in forecasting because i) they know the time at which an eruption column is forming; ii) they may collect all information needed for initializing models using monitoring systems and iii) they may verify the reliability of model results by comparing the computed data with the observed cloud trajectory and tephra deposit.

One of the most active volcanoes in the world is Mt. Etna, in Italy, characterized by explosive activity ranging from mild strombolian to sub-plinian. Activity occurs from the central craters (NEC, SEC, VOR, BN-1 and BN-2) (Fig. 1) and/or from fractures opened along the volcano flanks. In the last two decades the number of explosive events has increased (Branca and Del Carlo, 2005) and, because the volcanic plumes remained in the atmosphere from several hours to days, they forced several times the closure of the International Airport in Catania, only $30 \mathrm{~km}$ far from the volcanic vent. The most reported damages to aviation in Italy are, in fact, due to Etna's eruptions (Table 1, courtesy of M. Guffanti). On 3 August 1979, the airport of Catania had to close due to the large amount of ash fallout produced during an eruption from SEC (Romano and Sturiale, 1982; Chester et al., 1985). Major inconvenience occurred also on 24 September 1986, when NEC formed an eruption column of 10$13 \mathrm{~km}$ a.s.l. (Romano et al., 1986), and on 22 July 1998, when the eruption column reached $12 \mathrm{~km}$ a.s.l. (Andronico et al., 1999). Between 26 January and 24 June 2000, SEC produced 64 lava fountains forming weak plumes up to $6 \mathrm{~km}$ a.s.l. (Alparone et al., 2003). In particular, on 26 April 2000 an Airbus 320 taking off from Catania to Milan encountered volcanic ash and was forced to flight back to Catania (lieutenant colonel F. Colombo of Italian Air Force, personal communication; BGVN, 2000). The next year, an eruptive fracture opened at $2570 \mathrm{~m}$ a.s.l. producing a weak plume rising up to 5-6 km a.s.l. between 21 and 24 July that caused the cancellation of flight operations of Catania and Reggio Calabria airports (Scollo et al., 2007). Tephra fallout was also a significant phenomenon during the 2002-2003 Etna eruption (Andronico et al., 2005). Weak plumes having heights between 2.5 and $7 \mathrm{~km}$ a.s.l. (Andronico et al., 2008a) were almost continuously present between 27 October and the end of the explosive activity in December 2002. The International Airport of Catania was often forced to close to avoid accidents, causing considerable economic losses and inconveniences to the south-eastern population of Sicily. The airport was forced to close again on 24 November 2006 because ash fallout covered the SE flanks of the volcano.

In this context there was the demand to improve the monitoring and forecasting of the volcanic plume dispersal and tephra deposition during Etna explosive eruptions in a way to give precise warns to the aviation authorities via Italian Civil Protection, the national service for the emergency management in Italy, and to assist the work of VAACs. The ac-
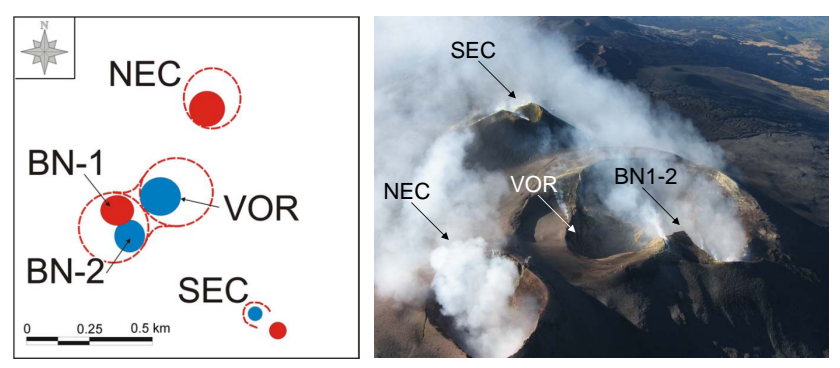

Fig. 1. Left: schematic map of the central craters of Etna volcano: North East crater (NEC), Voragine (VOR) and Bocca Nuova (BN-1, $\mathrm{BN}-2$ ) and South East crater (SEC). The outline lines represent the crater rim (photo courtesy of INGV-CT). Right: photopicture taken from D. Andronico on August 2007 during the monitoring activity of INGV-CT by helicopter surveys.

Table 1. Damages to aviation due to the volcanic ash in Italy.

\begin{tabular}{lll}
\hline Eruption Date & Volcano & City/Airport \\
\hline 22 Mar 1944 & Vesuvius & Naples/Terzigno \\
3 Aug 1979 & Etna & Catania/Fontanarossa \\
24 Sep 1986 & Etna & Catania/Fontanarossa \\
22 Jul 1998 & Etna & Catania/Fontanarossa \\
5 Jun 2000 & Etna & Catania/Fontanarossa \\
5 Jun 2000 & Etna & Catania/Sigonella \\
21-30 Jul 2001 & Etna & Catania/Fontanarossa \\
27 Oct 2002-28 Jan 2003 & Etna & Catania/Sigonella \\
27 Oct 2002-28 Jan 2003 & Etna & Reggio Calabria \\
27 Oct 2002-28 Jan 2003 & Etna & Catania/Fontanarossa \\
24 Nov 2006 & Etna & Catania/Fontanarossa \\
\hline
\end{tabular}

tions for reducing the hazard from tephra fall were developed during an ongoing specific project, the FIRB Italian project "Sviluppo Nuove Tecnologie per la Protezione e Difesa del Territorio dai Rischi Naturali" funded by Italian Minister of University and Research. The project leaded by the Istituto Nazionale di Geofisica e Vulcanologia, sezione di Catania (INGV-CT), the managing institution for the surveillance of Etna, has the aim to provide accurate and fast information on the evolution of the volcanic plumes during explosive eruptions of Etna.

In this paper we describe the approach used for monitoring and forecasting Etna volcanic plumes. Monitoring (Sect. 2) is carried out by using remote sensing systems for detecting the plume dispersal and the particle fallout. Forecasting (Sect. 3) is performed by combining four different models of tephra dispersal that were previously validated comparing simulations with field data collected during the monitoring activities of INGV-CT (e.g. Andronico et al., 2009). Automatic procedures, described here, were developed and made operative at INGV-CT since the end of 2006, when several explosive eruptive episodes occurred at SEC of Etna. Daily reports, edited during the activity, were very useful to the 
Italian Civil Protection for supporting their decisions during the emergencies. Finally, we address some future developments (Sect. 4) needed for improving the system.

\section{Monitoring system}

Timely volcanic plume observations may improve the forecast greatly. In fact, an efficient real time monitoring is crucial for aviation safety because it may evaluate input parameters needed for simulating tephra dispersal correctly and reduce the uncertainty of model outputs drastically. Real-time monitoring can be performed using both ground-based observations, located far or near the volcanic vent, and satellite images. Examples of near and far ground based observations are UHF wind profile applied for the first time at Etna between 11 and 12 October 1998 (Dubosclard et al., 1999, 2004), portable FM-CW radar used to evaluate the velocity of the explosions (Hort and Seyfried, 1998), acoustic instruments recently used to analyze sub-plinian plumes at Shishaldin volcano in Alaska (Vergniolle et al., 1996), meteorological radar systems (Harris et al., 1981; Lacasse et al., 2004; Rose et al., 1995), detectors of volcanic lightning (Mather and Harrison, 2006) and electric fields (Butter et al., 2000), visual, thermal, NIR cameras (Andò and Pecora, 2006). Geostationary or polar satellites are widely used to retrieve microphysical and morphological properties of volcanic ash plumes from satellite data (Prata and Grant, 2001). Actually, the instrumentation used at INGVCT consists of four cameras, one thermal camera, multispectral infrared measurements from the Spin Enhanced Visible and Infrared Imager on board the Meteosat Second Generation geosynchronous satellite (SEVIRI) and three continuous wave X-band disdrometers (PLUDIX).

Four cameras are available at INGV-CT for surveillance purposes. They are located in Catania, Nicolosi, Milo and Schiena dell'Asino (at about 27, 15, 11, and $5 \mathrm{~km}$ far from the vent). Further, one thermal camera located at Nicolosi is able to detect the presence of volcanic ash during the night. Surveillance cameras are very useful for detecting the height of eruption columns and analyze the style of explosive activity. Analysis of these images is used routinely at INGV-CT during Etna explosive activities (Alparone et al., 2007; Andronico et al., 2008a, b; Scollo et al., 2007).

Since August 2006 INGV-CT receives multispectral infrared measurements from EUMETSAT (European Organization for the Exploitation of Meteorological Satellites), an intergovernmental organization founded in 1986 and supported by 20 different European states. At present, EUMETSAT has five satellites, belonging to second generation meteorological satellites, being the most recent METEOSAT 8 and its backup METEOSAT 9. Each satellite has 12 spectral channels and delivers data with a temporal resolution of $15 \mathrm{~min}$. The spatial resolution of SEVIRI is $3 \mathrm{~km}$ for all channels except the HRV (High Resolution Visible) channel which is $1 \mathrm{~km}$. Although they have a lower resolution with respect to polar satellites (e.g. AVHRR), the high time resolution of geostationary satellites is more suitable for tracking plume purpose and sometimes used for providing quantitative information (e.g. height of eruption column). Just recently, a quantitative analysis was performed during the November 2005 eruption of Karthala volcano by using five infrared channels of SEVIRI centred at 6.2, 7.3, 8.5, 11 and $12 \mu \mathrm{m}$ (Prata and Kerkmann, 2007). The analysis of these IR images allowed to detect, for the first time, the separation between $\mathrm{SO}_{2}$ and volcanic ash. In addition, AVHRR images are elaborated by INGV, CNT-LABTEL of Rome for monitoring Etna volcanic plumes (Spinetti and Buongiorno, 2007) and delivered to INGV-CT every day.

Finally, three continuous wave X-band disdrometers (PLUDIX) are used to detect the ash fall rate. PLUDIX is a rain gauge disdrometer that detects the signal backscattered by hydrometeors and consists of a sensor, a signal processor and data communications unit. The sensor is a low power $(10 \mathrm{~mW})$ Continuous Wave (CW) Doppler radar operating at a frequency of $9.5 \mathrm{GHz}$ (Prodi et al., 2000). PLUDIX was tested for the first time during 2002-2003 Etna eruption and was able to measure terminal settling velocity of volcanic particles falling above the radar (Scollo et al., 2005). The instrument was considered as a helpful tool for the real-time monitoring because it can evaluate the particle fall rate and eventually the total grain-size distribution using inverse modelling. Two instruments are installed in Catania and Nicolosi, respectively at about 25 and $15 \mathrm{~km}$ from Etna volcanic vents, along the axes toward the Airport. The third instrument is used for performing measurements during explosive events.

\section{Forecasting plume dispersal and particle fallout}

Here we describe the automatic procedure used for forecasting ash dispersal and tephra deposit at INGV-CT. A good forecast need of: i) high-resolution meteorological data; ii) validated tephra dispersal models; iii) well-defined eruptive scenarios; iv) hazard map production by means of an automatic procedure. In the following sections each of these points is analyzed in detail.

\subsection{Meteorological data}

Weather data furnished by meteorological models are needed to forecast plume dispersal and tephra deposit correctly. Meteorological models are classified in Global when their domain is the Earth, Regional or Limited-Area models when instead they cover part of the Earth. Examples of Global models are GFS (Global Forecast Service), developed by NOAA (National Oceanic and Atmospheric Administration) in USA, NOGAPS, developed by US Navy in USA, or ECMWF developed by the European Centre for Medium-Range Weather. Examples of regional models 
are MM5, developed in cooperation between the Pennsylvania State University (Penn State) and the University Corporation for Atmospheric Research, LAMI (Limited Area Model Italy) developed by the European Consortium for Small-Scale Modelling (COSMO). Metereologists tipically use an international public format GRIB (GRIdded Binary) standardized by WMO (World Meteorological Organization) packed in a binary format for increasing the storage efficiency.

Daily, INGV-CT receives weather forecasts from the Italian Air Force Meteorological Office (in Italian acronym CNMCA) in Rome and from the hydrometeorological service of ARPA in Emilia Romagna (ARPASIM). CNMCA furnishes the GRIB files every $24 \mathrm{~h}$ in 16 files having a time step of $3 \mathrm{~h}$; therefore the weather forecasts are covered for $48 \mathrm{~h}$. The $\mathrm{CN}$ MCA grid covers an area from $12.5^{\circ}$ and $18.5^{\circ} \mathrm{E}$ and $34.5^{\circ}$ and $40.5^{\circ} \mathrm{N}$, with $101 \times 101$ points stepped by $0.06^{\circ}$ and has 13 isobaric levels. Instead, the ARPASIM GRIB files are given every $12 \mathrm{~h}$ with a time step of $1 \mathrm{~h}$ and the weather forecasts are given until $72 \mathrm{~h}$. The ARPASIM grid covers an area rotated with respect to the Equator that is moved to the medium latitudes. It spans from $1^{\circ}$ to $7.25^{\circ} \mathrm{E}$ and from $-23^{\circ}$ to $17.65^{\circ} \mathrm{N}$ and has 22 isobaric levels. The GRIB files are formed from $101 \times 101$ points stepped by $0.0625^{\circ}$. Every hour an ftp application logins automatically at CNMCA and ARPASIM ftp web-sites for downloading the GRIB files which are then stored at INGV-CT. If the connection closes accidentally, the application preserves the date of the last file that was downloaded, in a way to reconnect to the same file in the next connection. The data are plotted automatically on a monitor at INGV-CT operative room where two operators watch for the activity of Sicilian volcanoes on 24/7 and alert Italian Civil Protection authorities in case of eruption. The forecast of wind direction and speed, cloud cover, temperature, precipitation are visualized in a desktop by the VISUALGRIB software developed at INGV-CT within this project (Fig. 2).

\subsection{Tephra dispersal models}

Tephra dispersal models solve the advection-diffusion equation by using different approaches and may be grouped in two main categories: Lagrangian and Eulerian. In the Lagrangian approach particle motion is considered to consist of two terms, i.e. a deterministic part due to the wind transport plus a random walk process which describes diffusion due to turbulence. The plume dispersion is evaluated applying a statistical analysis on the trajectories of a large number of particles. Instead in the Eulerian description the movement of the plume is observed on specific points in the space through which the plume moves. The advection-diffusion equation can be also solved by using analytical methods (providing exact solutions) under appropriate approximation or by using numerical methods (providing instead approximate solutions of the full differential equation). In Volcanology, Lagrangian models are used to forecast tephra dispersal for aviation operation applications (Barsotti and Neri, 2008; D'Amours, 1998; Heffter and Stunder, 1993; Searcy et al., 1998). Eulerian models are used to analyze the turbulent dispersion and deposition of particles in a wind field (e.g. Armienti et al., 1988; Glaze and Self, 1991, Carey and Sparks, 1986; Woods et al., 1995), or to analyze the large-eddy sedimentation from plume margins combined with gravity-driven intrusion at the neutral buoyancy level (e.g. Bursik et al., 1992a, b; Koyaguchi and Ohno, 2001a, b; Bonadonna and Phillips, 2003). Under simplifying assumptions the equation for the mass conservation describing the plume dispersion, admits an analytical solution obtained as a Gaussian distribution (the simplified analytical Eulerian models are known as Gaussian models). These models have been extensively used to make probability maps of the tephra fallout (Bonadonna et al., 2005; Cioni et al., 2003; Macedonio et al., 2008) because they allow performing a great number of simulations fastly and hence make reliable the statistical analysis.

Four different tephra dispersal models are run at INGVCT daily. They are HAZMAP (Macedonio et al., 2005), TEPHRA (Bonadonna et al., 2005), PUFF (Searcy et al., 1998) and FALL3D (Costa et al., 2006). HAZMAP is a two dimensional dispersal model that solves semi-analytically the advection-diffusion equation. The model was previously applied to evaluate the tephra fallout risks at Vesuvius (Barberi et al., 1990) and the hazard assessment associate with dome-collapses and the vulcanian explosions on Montserrat (Bonadonna et al., 2002). HAZMAP was also used by Pfeiffer et al. (2005) to reconstruct the $79 \mathrm{AD}$ plinian eruption of the Vesuvius and by Scollo et al. (2007) to model the dispersal of the weak and long-lasting plume formed between 21 and 24 July 2001 at Etna. TEPHRA (like HAZMAP) is an advection-diffusion model based on several theories (Armienti et al., 1988; Bonadonna et al., 1998, 2002; Bursik et al., 1992a; Connor et al., 2001; Suzuki, 1983) and written for parallel computing on a Beowulf cluster. The model has been already calibrated on two explosive Etna eruptions occurred on 22 July 1998 and between 21 and 24 July 2001 and used to perform the hazard assessment from tephra fall of Etna volcano (Scollo et al., 2006). PUFF is a Lagrangian model (Searcy, 1998). The model requires 3-D atmospheric data and the DEM of the area affected by the fallout. PUFF is able to locate at any time the position of thousands particles that are released from the volcano and then advected, diffused, and settled within the atmosphere. An example of the model application to Etna is presented by Aloisi et al. (2002) in which the 22 July 1998 plume is simulated and compared with SEVIRI images. Finally, FALL3D (Costa et al., 2006; Folch et al., 2009) is a 3-D Eulerian model for the transport and deposition of volcanic ash which is coupled with global and mesoscale meterological models and uses the gradient transport theory for the turbulent diffusion and buoyancy plume theory for the eruption column. FALL3D runs at INGV-CT, inside the APOLLO platform (Folch et al., 


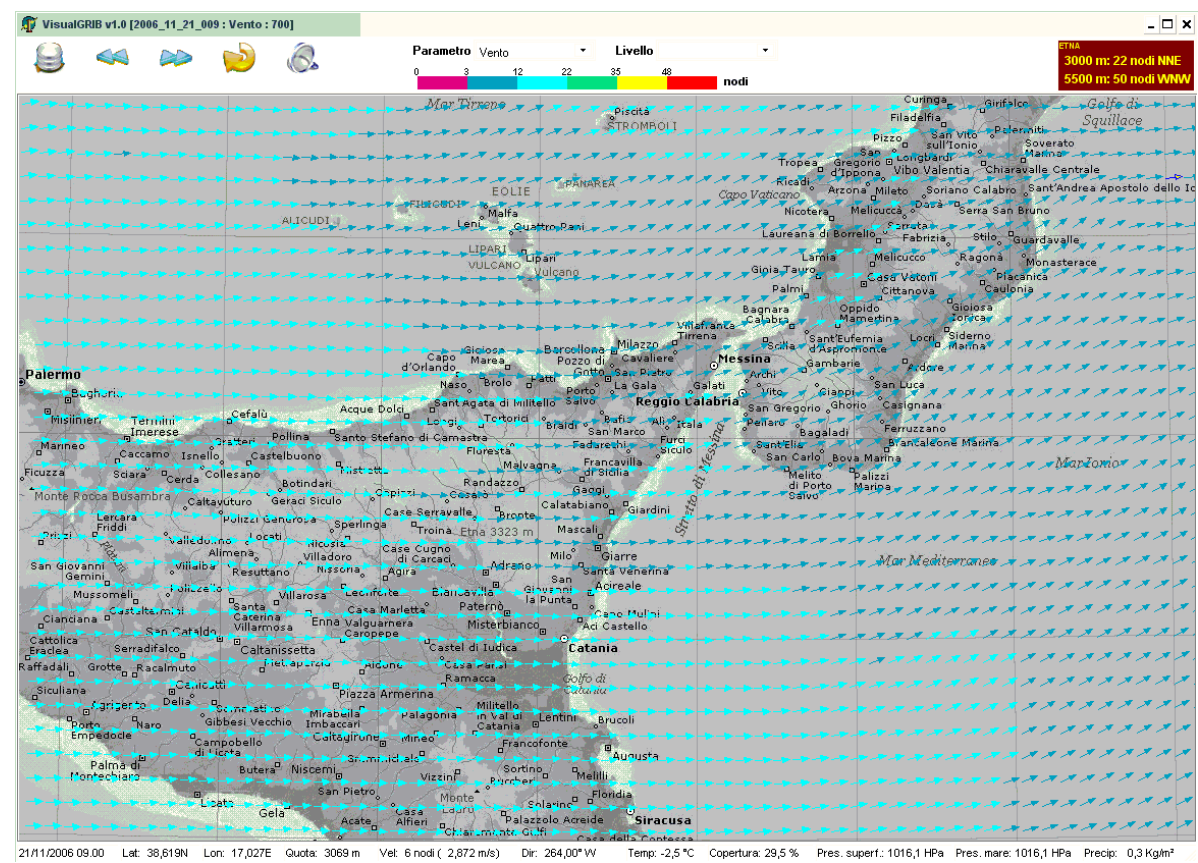

Fig. 2. VISUALGRIB software able to plot the forecast of wind direction and speed, cloud cover, temperature and precipitation for two days.

2008a), platform-independent procedure designed to generate data input for all models installed in the platform, run these and plot their results with equal isomass curves for a user-friendly analysis. FALL3D has been already validated successfully comparing the computed deposit with field data of 2001 Etna eruption (Costa et al., 2006), amongst several other eruptions worldwide.

\subsection{Eruptive scenarios}

Tephra dispersal models require the following input parameters: erupted mass, column height, total grain-size distribution and particle shape. The constrain of these parameters is usually given by analysis of field data collected during the monitoring activities of INGV-CT (Alparone et al., 2007; Andronico et al., 2009). However, two different typologies of explosive activity have been identified at Etna (Scollo, 2006): one producing strong and short-lasting plumes and another producing weak and long-lasting plume. Forecast of the plume dispersal is based on simulations of different Etna eruptions, each belonging to one of these two typologies: the eruption of 22 July 1998 (Andronico et al., 1999), of 2124 July 2001 (Scollo et al., 2007), and finally of 2002-2003 (Andronico et al., 2008a).

Scenario 1 was chosen similar to the eruption occurred on 22 July 1998. During 22 July 1998 Etna formed an eruption column rising $12 \mathrm{~km}$ a.s.l. (Fig. 3) and a tephra deposit covering the SE flanks of the volcano. Wind direction was almost constant toward SE for altitudes up to $10 \mathrm{~km}$ (about 140 from the north). Wind speed ranged between 4 and

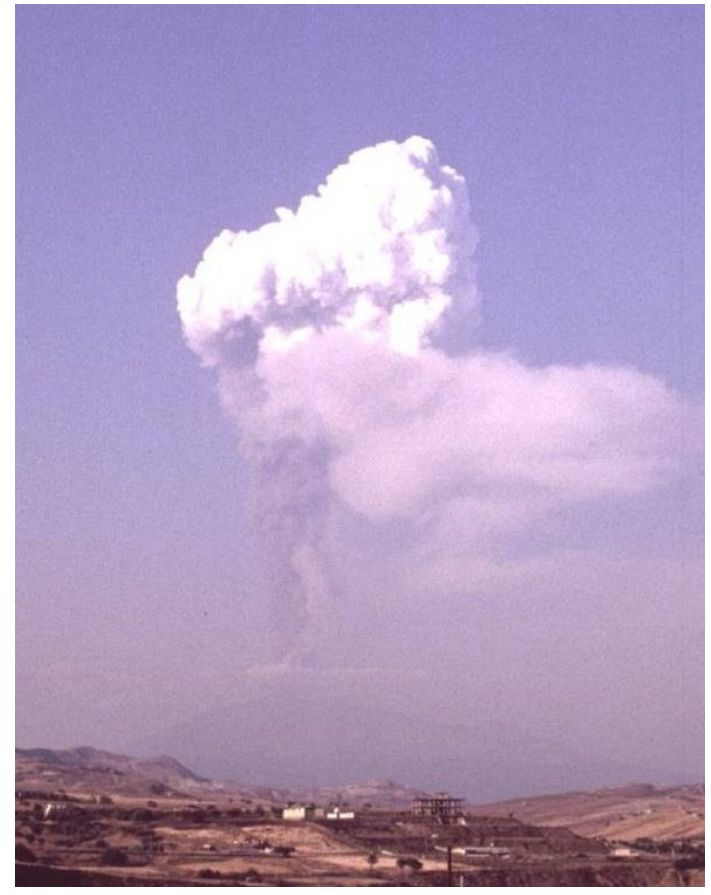

Fig. 3. Eruption column produced during the activity of 22 July 1998. Photo courtesy of M. Pompilio.

$6 \mathrm{~m} \mathrm{~s}^{-1}$ at about $1 \mathrm{~km}$ a.s.l. and between 9 and $11 \mathrm{~m} \mathrm{~s}^{-1}$ at about $16 \mathrm{~km}$ a.s.l. (Aloisi et al., 2002). After the eruption, Andronico et al. (1999) collected 35 samples on the SE flanks and classified the eruption as sub-plinian according to 
the analysis of the deposit. They estimated a total erupted mass of $1.3 \times 10^{9} \mathrm{~kg}$ using the method by Walker (1973). The total grain-size distribution was instead evaluated using the Voronoi's method (Bonadonna and Houghton, 2005) as a Gaussian distribution peaked at $2.3 \pm 1.5 \phi$ (Scollo et al., 2008a).

Scenario 2 is similar to the $21-24$ July 2001 eruption. During 21-24 July 2001 a weak and long-lasting plume produced by a phreatomagmatic activity (Fig. 4) rose up to $5-6 \mathrm{~km}$ a.s.l. from a volcanic vent opened at $2570 \mathrm{~m}$ on the S flank of the volcano. 46 samples were collected in this case on the SE flanks and analyzed in detail by using both field data standard analysis and modelling (Scollo et al., 2007). The total mass was equal to $2.3 \times 10^{9} \mathrm{~kg}$ using the Power law's method and a total grain-size distribution at $2.0 \pm 1.5 \phi$ using Voronoi's method (Bonadonna and Houghton, 2005).

Finally Scenario 3 was chosen similar to the 2002-2003 eruption. The 2002-2003 Etna eruption was amongst of the most explosive events of the last centuries. The explosive activity began on 27 October 2002 (Fig. 5) and persisted up to 20 December while the eruptive activity ended definitely on 28 January 2003. The heights of eruption columns, estimated by combining barometrical altimeter data during over-flights with the analysis of images and videos, ranged from 3.3 to $7 \mathrm{~km}$ a.s.l.. Tephra sampling carried out on 27, 28, 31 October and 4 November allowed to estimate a total erupted mass of $4.4 \times 10^{10} \mathrm{~kg}$ and a total grain-size distribution of $0.5 \phi$ (Andronico et al., 2008a). Simulations showed that the E flanks of the volcano were mainly affected from the tephra fallout and that also basaltic volcano as Etna can produce a huge amount of volcanic ash (Andronico et al., 2008a).

Input parameters for modelling (Table 2) were obtained by the analysis of the deposits collected after few hours from the eruptive event. Only the duration was modified being $5 \mathrm{~min}$ for Scenario 1 and three hours (like the time step of the wind forecast data) for Scenarios 2 and 3.

\subsection{Hazard map production}

We implemented an automatic procedure for publishing hazard maps of plume dispersal and particle fallout for the considered scenarios. The system is supervised by a "scheduler", software developed in this project (Fig. 6) which checks if each process has run correctly in the right sequence, and ended regularly; otherwise it sends an e-mail to alert that some errors have occurred. The scheduler makes the acquisition of meteorological data, and decides also which of the two weather forecasts is used to run simulations. When all the GRIB files are downloaded, an application converts these files in ASCII and NetCDF formats to be readable by TEPHRA and PUFF models, respectively. The APOLLO platform (Folch et al., 2008a) reads directly from the GRIB files; consequently we only set inputs to run with both the CNMCA and ARPASIM files. Every $3 \mathrm{~h}$, volcanic ash dispersal and tephra fallout occurring from the Scenarios 1, 2

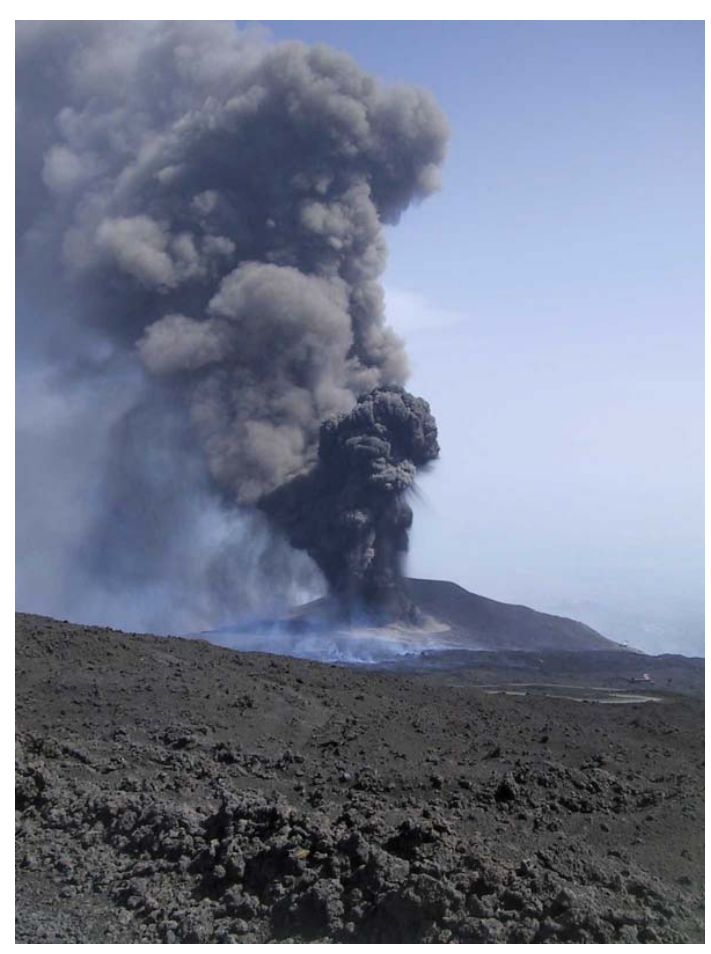

Fig. 4. Eruption column produced during the activity of 24 July 2001. Photo taken during the monitoring activity of INGV-CT.

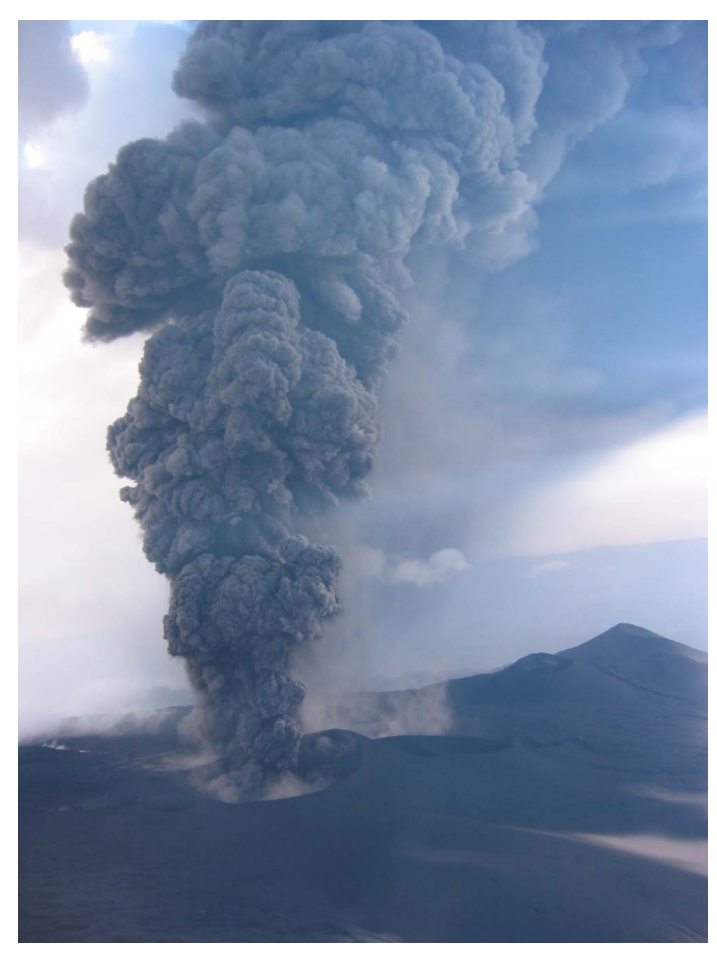

Fig. 5. Eruption column produced during the activity of November 2002. Photo taken during the monitoring activity of INGV-CT. 


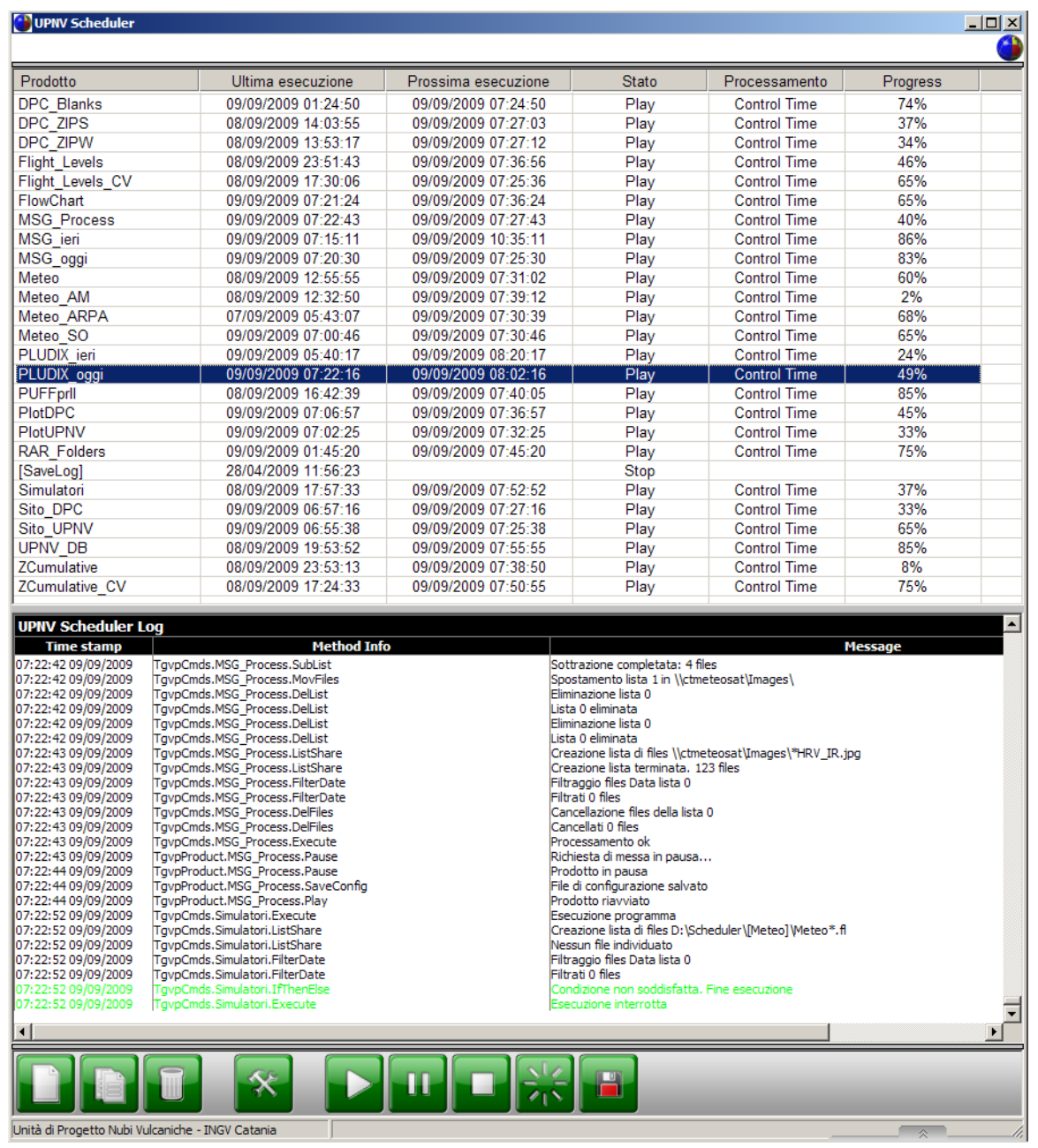

Fig. 6. Software which controls the processes of monitoring and forecasting at INGV-CT.

and 3, are simulated. All codes run on a Beowulf cluster composed by 24 Opteron bi-processor nodes, and the results of TEPHRA, PUFF, HAZMAP, FALL3D are plotted on geo-referenced maps in the air and on the ground automatically. Finally, the scheduler publishes them into two websites, one visible only by Italian Civil Protection (Fig. 7), in which SEVIRI and AVHRR (given from INGV, CNTLABTEL of Rome) images are plotted together with hazard maps of TEPHRA and PUFF, and one in which hazard maps of different simulators are plotted together for studying their differences and helping for a better quantification of the uncertainties associated with a forecast (this work is in progress with INGV, sezione di Napoli, and INGV, sezione di Pisa).

\section{Application to Etna}

Although the project was at an early stage, the occurrence of several explosive events at Etna since 2006 forced us to make operative the previously described system. The result was
Table 2. Input parameters of Scenarios 1, 2 and 3 used for forecasting plume dispersal and tephra deposit at INGV-CT; MER is for Mass Eruption Rate, CH for Column Height, TGS for Total GrainSize distribution.

\begin{tabular}{lllllll}
\hline $\begin{array}{l}\text { Eruptive } \\
\text { scenarious }\end{array}$ & Duration & $\begin{array}{l}\text { MER } \\
(\mathrm{kg} / \mathrm{s})\end{array}$ & $\begin{array}{l}\mathrm{CH} \\
(\mathrm{km})\end{array}$ & $\begin{array}{l}\text { TGS } \\
(\phi)\end{array}$ & $\begin{array}{l}\text { Etna } \\
\text { eruption }\end{array}$ \\
\hline Scenario 1 & $5 \mathrm{~min}$ & $1 . \mathrm{E}+06$ & 8 & 2 & 1.5 & 1998 \\
Scenario 2 & $3 \mathrm{~h}$ & $5 . \mathrm{E}+03$ & 2 & 2 & 1.5 & 2001 \\
Scenario 3 & $3 \mathrm{~h}$ & $1 . \mathrm{E}+05$ & 4 & 0.5 & 1.5 & $2002-2003$ \\
\hline
\end{tabular}

the production of several reports on the forecasting and the detection of volcanic plumes available on-line at http://www. ct.ingv.it. These reports were very useful to the Italian Civil Protection which from that time requires these hazard maps from INGV-CT daily. This work gave us the opportunity to estimate the reliability and accuracy of the system from the beginning of the project and suggested future improvements. 


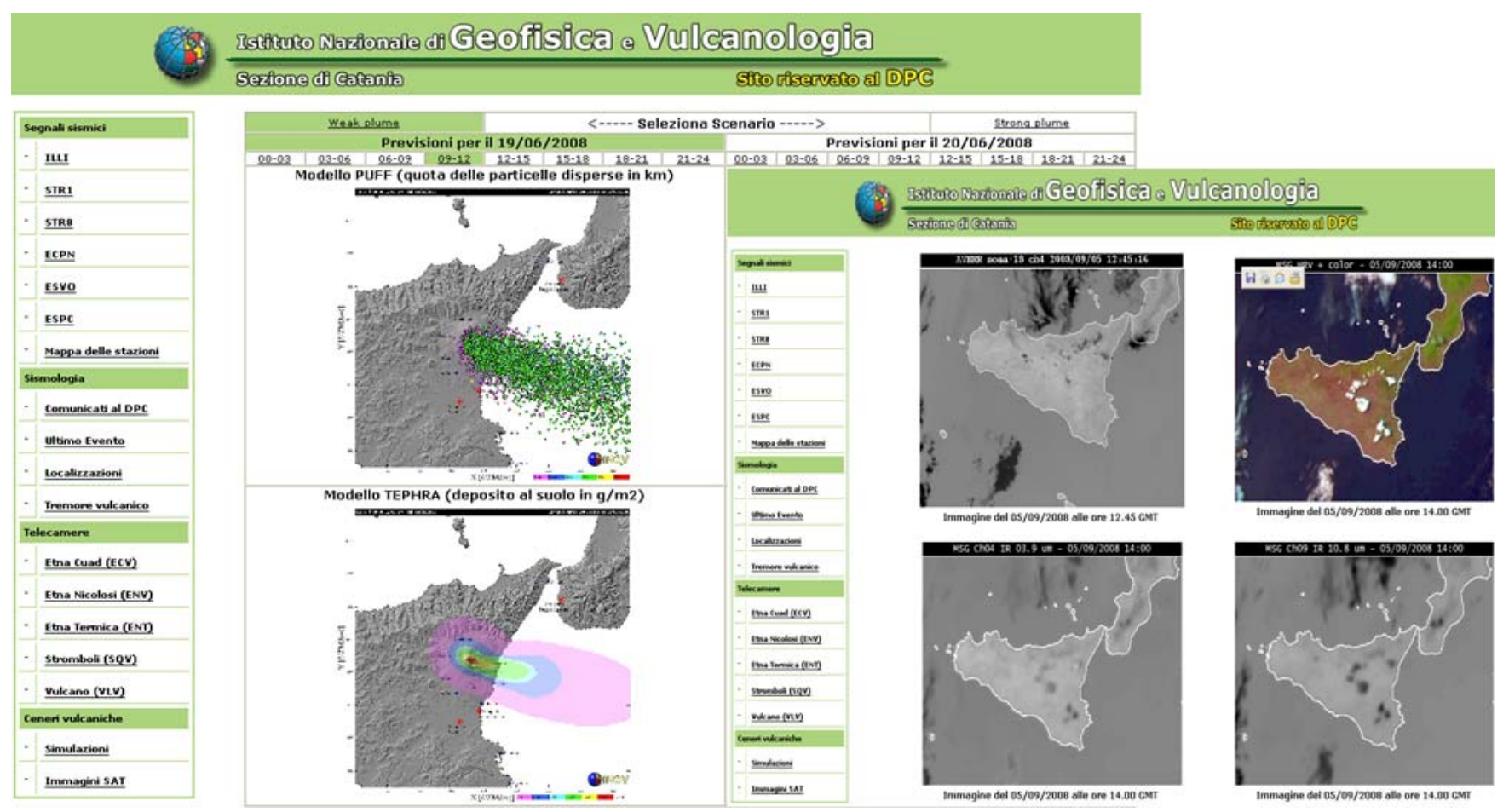

Fig. 7. Web-site dedicated to the Italian Civil Protection in which the satellite images and ash forecasting are visualized.

We report two examples in which the system was applied successfully, 24 November 2006 and 4-5 September 2007.

On 24 November, SEC produced one of the most relevant paroxysms of 2006. A weak plume started at 02:19 GMT and lasted for about ten hours. Bombs and blocks reached heights up to $200 \mathrm{~m}$ (De Beni et al., 2006) and tephra fallout affected mainly the south-east volcano sector between Giarre and Siracusa (Andronico et al., 2007) causing the closure of the international airport of Catania. The plume moved from SE toward SSE at about 11:30 GMT due to the variation of the wind direction, action confirmed by the HRV images of SEVIRI. Figure 8 shows the plume dispersal as retrieved by SEVIRI, in good agreement with the FALL3D and HAZMAP simulations for Scenario 2. Further, it is notable as the shift from SE towards SSE was also computed by the numerical simulation (e.g. TEPHRA forecasting in Fig. 9).

During 4 September 2007 a powerful lava fountain started at 14:00 GMT from SEC producing a volcanic plume, about $5 \mathrm{~km}$ a.s.l. in high that kept the same direction for almost $12 \mathrm{~h}$ (Andronico et al., 2008b). The associated tephra deposit covered the E flanks of the volcano between Piedimonte to the $\mathrm{N}$ and Sarro and Guardia Mangano to S. The deposit was analyzed in detail by Andronico et al. (2008b) who estimated a total volume of $3.9 \times 10^{8} \mathrm{~kg}$ and a total grain-size distribution peaked at $0 \phi$. The TEPHRA and PUFF simulations for Scenario 2 computed the plume dispersal and tephra deposit toward $\mathrm{E}$ as confirmed by satellite images (Fig. 10). In this case, flights landed from NW, the opposite side of the plume, and the International Airport of Catania did not have to close.

\section{Future developments and conclusions}

Three pre-defined eruptive scenarios run daily at INGV-CT (corresponding to the 1998, 2001 and 2002-2003 Etna eruptions). However, it is evident that a new eruption could differ from these scenarios significantly and, consequently, the simulations may differ from the real dispersion. Recent studies have shown that due to the high variability of Etna explosive activity (Andronico and Scollo, 2008) the use of predefined scenarios could be limiting. However, the number of scenarios can not be increased because of high time for computing the model outputs even using computing techniques. Otherwise, several typologies of eruptions could be studied in detail extracting input parameters for tephra dispersal models. Hence, the volcanologist on duty could choose, on the base of information obtained by the monitoring system, input parameters belonging to a given typology with similar features of the ongoing eruption.

Techniques of data assimilation could be also used. In fact, recent parametric studies have shown that the output of models can be strongly sensitive to the uncertainties on input parameters (Connor and Connor, 2006; Scollo et al., 2008a, b). For giving a reliable ash forecasting, mass eruption rate, column height, distribution of the mass along the column and grain-size distribution should be well constrained. Because many of these parameters are lacking during an eruption, a possible approach could be to simulate the event using semi-quantitative volcanological input parameters based 


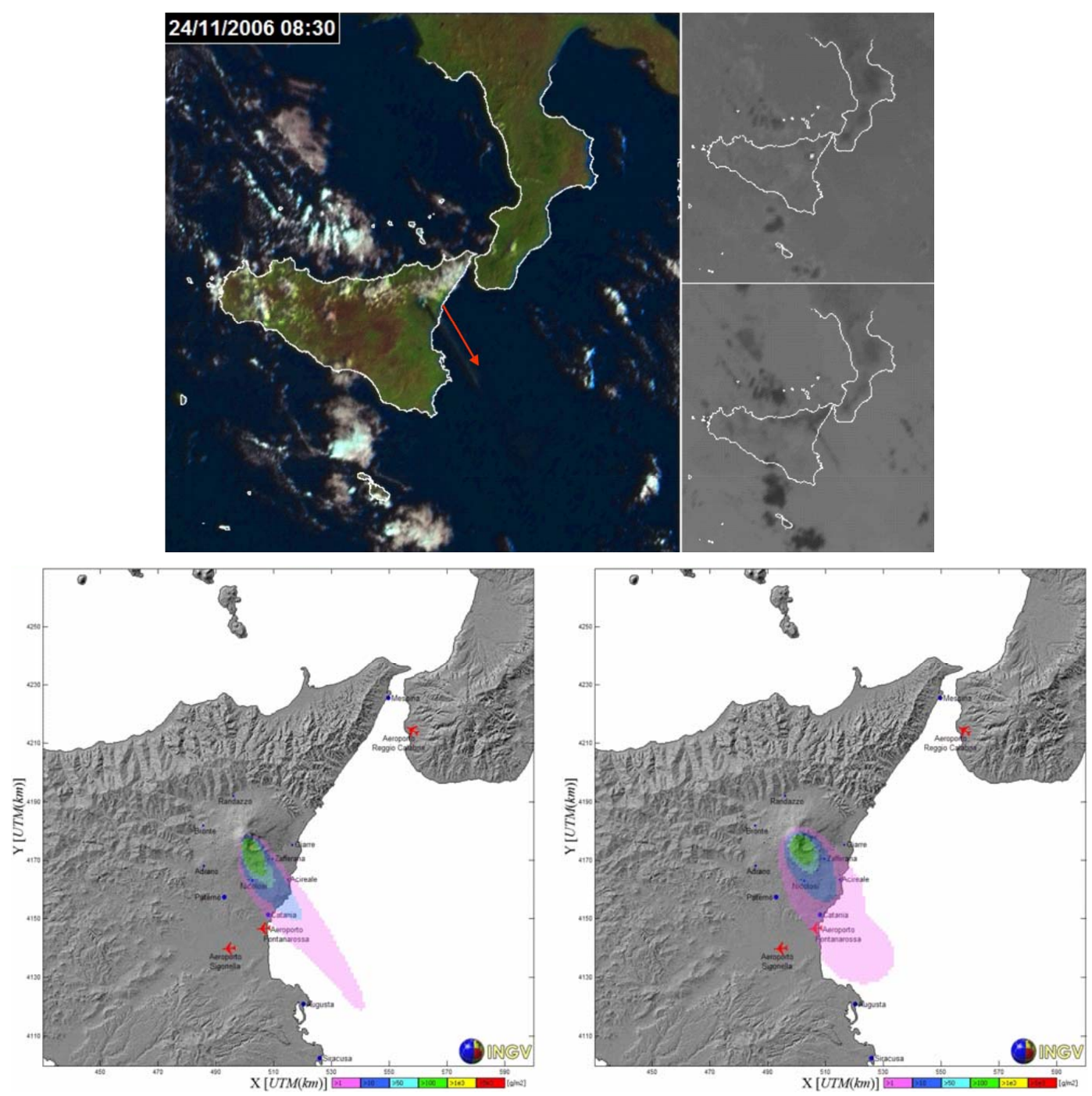

Fig. 8. SEVIRI images showing the plume dispersal toward SE on 24 November 2006 at 08:30 GMT and FALL3D and HAZMAP simulations of Scenario 2.

on the first eruption reported data. This method was applied by Folch et al. (2008b) to forecast tephra dispersal during the May 2008 Chaitén eruption. In this case, mass eruption rate was evaluated from the column height (available from several reports) and kept constant during the simulation (this approach led to an overestimation of the erupted mass). They used a 1-D radially-averaged Buoyant Plume Theory model for the distribution of the mass along the column and a grainsize distribution representative of a sub-plinian eruption. Due to several assumptions on input parameters, this strategy has to be considered as a first order semi-quantitative approach, as also highlighted by Folch et al. (2008b). The forecasting system described in this paper can be also considered semiquantitative due to the use of defined scenarios. However, note that this static approach is the only method able to furnish fast information on the plume dispersal and tephra fallout. Afterward, it is evident as the future developments in volcanic ash forecasting should be addressed to collect data from the monitoring instruments, transform them into input parameters for tephra dispersal models in a way to make more reliable simulations. This could be carried out using techniques of data assimilation already widely used in meteorological fields. New instruments and/or techniques able to detect the key parameters for models should be developed and make operative in observatories like INGV-CT. All models available in this project have already been tested and validated on data collected during the 2001 Etna eruptions (e.g. FALL3D, Costa et al., 2006). However, these studies have showed the need of reducing the model uncertainty by improving the modelling of some processes still now unknown (e.g. influence of particle shape, aggregation processes, and rain scavenging). Since the last years techniques of ensemble forecasting have been recently developed for analyzing the limitation imposed by the uncertainties in the prediction and 

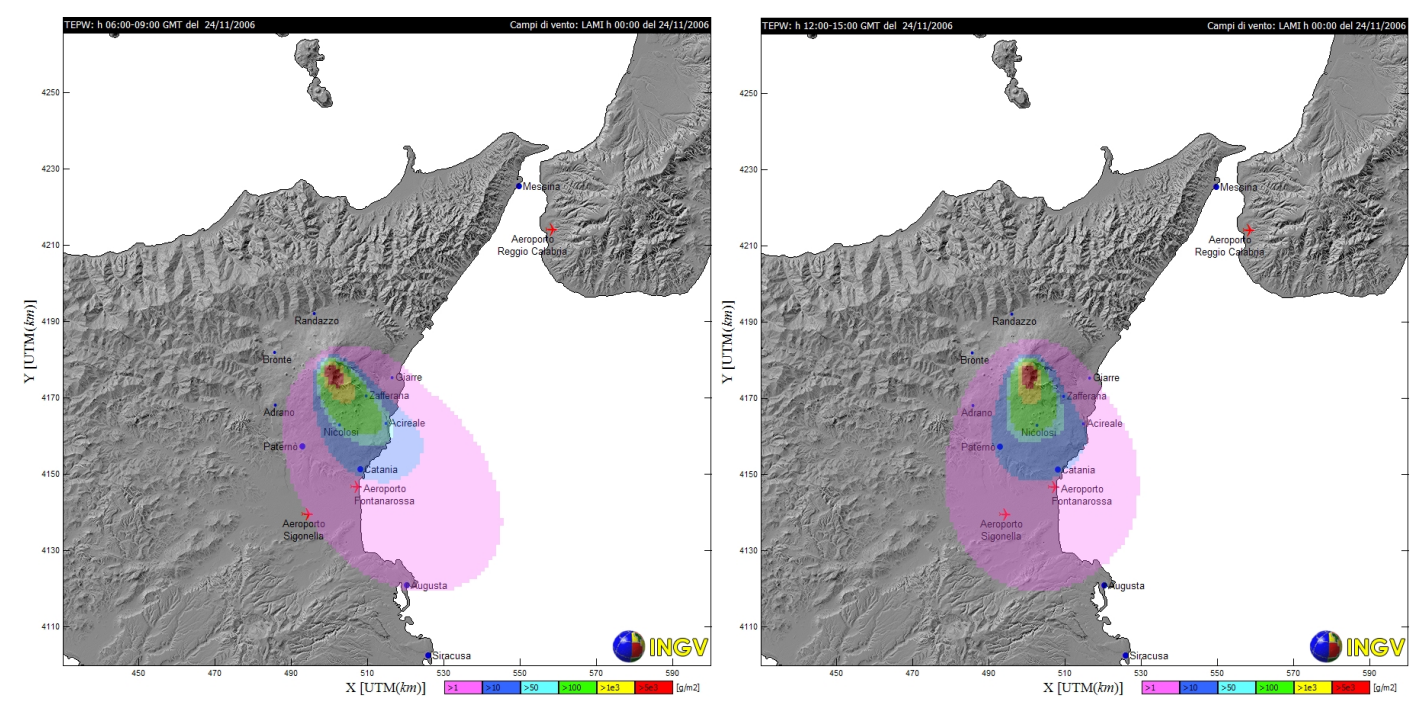

Fig. 9. Shift of the volcanic plume modelled by TEPHRA reflecting the changing of the wind direction from SE to SSE.
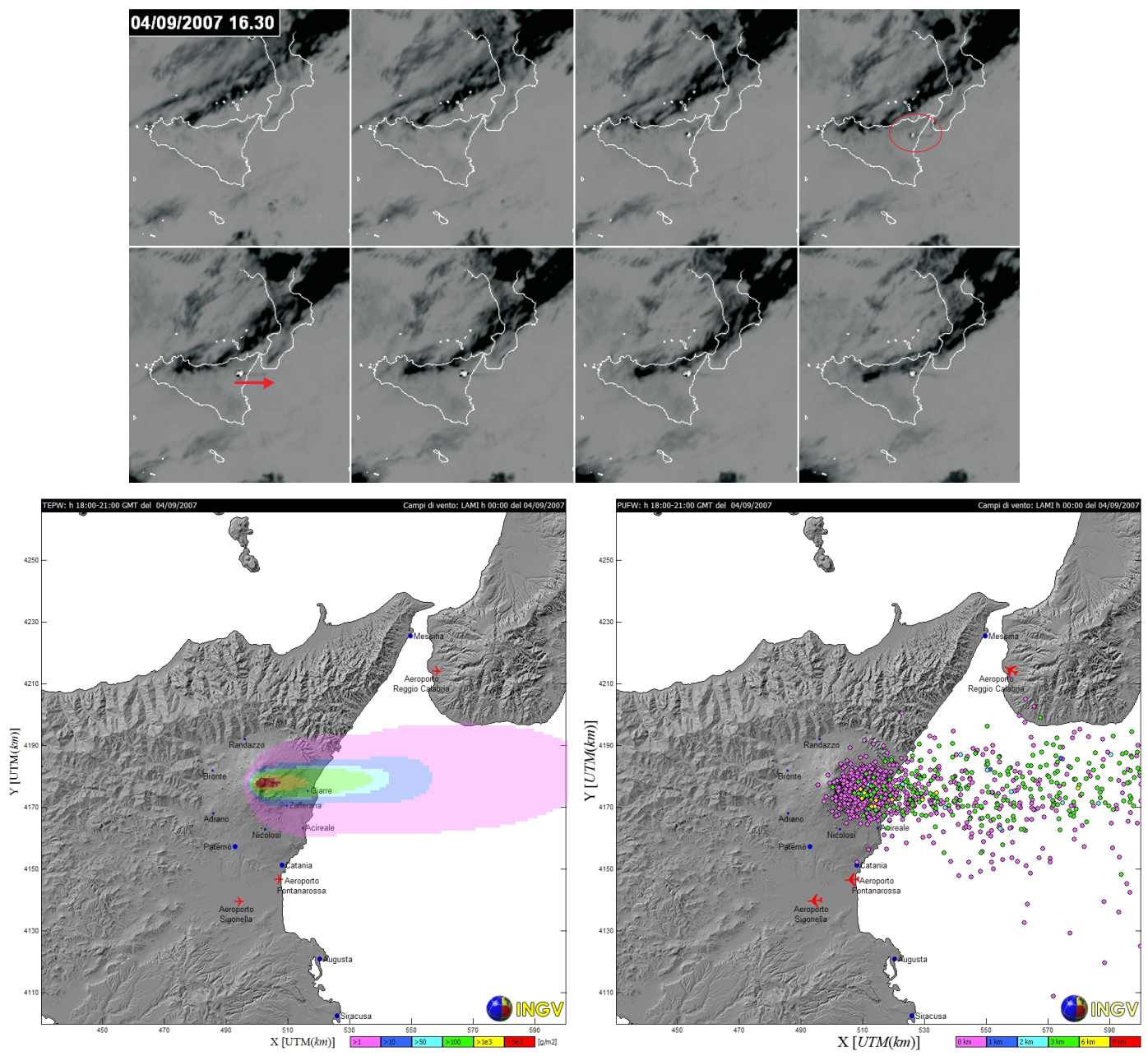

Fig. 10. SEVIRI images from 16:30 to 18:15 GMT of 4 September 2007 with steps of 15 min showing the ash plume toward E and TEPHRA and PUFF simulations of Scenario 2. 
estimate quantitatively the probability density of the state of atmosphere at a specific time (Leutbecher and Palmer, 2008). At the moment we are beginning to compare the results of five dispersal models (this work is going on with the collaboration of INGV, sezione di Pisa, and INGV, sezione di Napoli). The same technique could be used in forecasting ash dispersal in a way for example to evaluate the probability density that volcanic ash is found in a specific space and time during an explosive eruption.

In summary, the forecasting and monitoring system developed at INGV-CT can be described as following: weather forecast data are downloaded from ARPA-SIM and CNMCA daily and four tephra dispersal models (FALL3D, HAZMAP, PUFF, TEPHRA) using input parameters for three predefined eruptions at Etna every three hours. Finally hazard maps are plotted and uploaded to web-site. The forecasts are validated using data from visible and thermal cameras, SEVIRI images and PLUDIX instruments. Further, the use of the field data collected after the explosive event is also crucial to evaluate the reliability of the simulations.

This paper shows that multidisciplinary approaches are needed to improve any type of forecasting. In fact, only the use of instruments able to detect different aspects of the same eruptive phenomena combining with advanced tephra dispersal models available in literature can give useful information on the presence of volcanic ash in the air and on the ground and consequently to prevent damages and airport disruptions.

Acknowledgements. The authors thank A. Costa, A. Folch and G. Macedonio for assisting the installation of the APOLLO platform at INGV-CT, C. Bonadonna, L. Connor and C. Connor for the TEPHRA model and R. Peterson for the PUFF model. A. Bonaccorso, director of INGV-CT during the most part of the project, who allows to make operative the forecasting and monitoring system at INGV-CT since the 2006 Etna activity. The authors thank the Italian Civil Protection and the Air Force that help to improve the system. D. Reitano, F. Barberi, R. S. J. Sparks and E. Boschi are also thanks for encouragements to develop the system. The INGV, sezione di Napoli, INGV CNT-LABTEL, sezione di Roma and INGV, sezione di Pisa are thanks for several useful discussions. We greatly thank A. Costa and A. Folch for their valuable reviews that improved the quality of the paper. This work is supported by the FIRB Italian project "Sviluppo Nuove Tecnologie per la Protezione e Difesa del Territorio dai Rischi Naturali" funded by Italian Minister of University and Research for three of the authors (M. Prestifilippo, G. Spata and S. Scollo).

Edited by: J. Marti

Reviewed by: A. Folch and A. Costa

\section{References}

Aloisi, M., D’Agostino, M., Dean, K. G., Mostaccio, A., and Neri, G.: Satellite analysis and PUFF simulation of the eruptive cloud generated by the Mount Etna paroxysm of 22 July 1998, J. Geophys. Res., 107(B12), 2373, doi:10.1029/2001JB000630, 2002.
Alparone, S., Andronico, D., Lodato, L., and Sgroi, T.: Relationship between tremor and volcanic activity during the Southeast Crater eruption on Mount Etna in early 2000, J. Geophys. Res., 115(B4), 2241, doi:10.1029/2002JB001866, 2003.

Alparone, S., Andronico, D., Sgroi, T., Ferrari, F., Lodato, L., and Reitano, D.: Alert system to mitigate tephra fallout hazards at Mt. Etna Volcano, Italy, Nat. Hazards, 43, 333-350, 2007.

Andò, B. and Pecora, E.: An advanced video-based system for monitoring active volcanoes, Comput. Geosci., 32, 85-91, 2006.

Andronico, D., Del Carlo, P., and Coltelli, M.: The 22 July 1998 fire fountain episode at Voragine Crater (Mt Etna, Italy), Volcanic and Magmatic Studies Group, Annual Meeting, 1999.

Andronico, D., Cristaldi, A., Lo Castro, D., Scollo, S., and Taddeucci, J.: The 24 November 2006 paroxysm at south-east crater, Mt. Etna, IUGG, 2-13 July, Perugia, Italy 2007.

Andronico, D., Branca, S., Calvari, S., et al: A multi-disciplinary study of the 2002-03 Etna eruption: insights for a complex plumbing system, B. Volcanol., 67(4), 314-330, 2005.

Andronico, D., Scollo, S., Caruso, S., and Cristaldi, A.: The 2002-03 Etna explosive activity: Tephra dispersal and features of the deposits, J. Geophys. Res., 113, B04209, doi:10.1029/2007JB005126, 2008a.

Andronico, D., Cristaldi, A., and Scollo, S.: The 4-5 September 2007 lava fountain at South-East Crater of Mt Etna, Italy, B. Volcanol., 70, 1103-1112, 2008b.

Andronico, D. and Scollo, S. 1998-2007: Ten years of explosive activity at Mt. Etna volcano, IAVCEI 2008 General Assembly, Reykjavík, Island, 18-24 August 2008.

Andronico, D., Scollo, S., Cristaldi, A., and Ferruccio, F.: Monitoring ash emission episodes at Mt. Etna: The 16 November 2006 case study, J. Volcanol. Geoth. Res., 180, 123-134, 2009.

Armienti, P., Macedonio, G., and Pareschi, M. T.: A numericalmodel for simulation of tephra transport and deposition - applications to May 18, 1980, Mount-St-Helens eruption, J. Geophys. Res., 93, 6463-6476, 1988.

Barberi, F., Macedonio, G., Pareschi, M., and Santacroce, R.: Mapping the tephra fallout risk: an example from Vesuvius(Italy), Nature, 344, 142-144, 1990.

Barsotti, S. and Neri, A.: The VOL-CALPUFF model for atmospheric ash dispersal: 2. Application to the weak Mount Etna plume of July 2001, J. Geophys. Res., 113, B03209, doi:10.1029/2006JB004624, 2008.

Blong, R. J.: Volcanic Hazard, a Sourcebook on the Effects of Eruptions, Academic Press, Sidney, 1984.

BGVN, Additional descriptions of April-May eruptions and aircraft damaged by tephra-fall (2000) Report n. 09/2000, available at: http://www.volcano.si.edu/world/volcano.cfm?vnum= 0101-06 $=\backslash \&$ volpage $=$ var, 2000.

Bonadonna, C., Ernst, G. G. J., and Sparks, R. S. J.: Thickness variations and volume estimates of tephra fall deposits: the importance of particle Reynolds number, J. Volcanol. Geoth. Res., 81, 173-187, 1998.

Bonadonna, C., Macedonio, G., and Sparks, R. S. J.: Numerical modelling of tephra fallout associated with dome collapses and Vulcanian explosions: application to hazard assessment on Montserrat, in: The eruption of Soufrière Hills Volcano, Montserrat, from 1995 to 1999, edited by: Druitt, T. H., Kokelaar, B. P., Geological Society, London, Memoir, 2002.

Bonadonna, C. and Phillips, J. C.: Sedimentation from 
strong volcanic plumes, J. Geophys. Res., 108(B7), 2340, doi:10.1029/2002JB002034, 2003.

Bonadonna, C., Connor, C. B., Houghton, B. F., Connor, L., Byrne, M., Laing, A., and Hincks, T. K.: Probabilistic modeling of tephra dispersal: Hazard assessment of a multiphase rhyolitic eruption at Tarawera, New Zealand, J. Geophys. Res., 110, B03203, doi:10.1029/2003JB002896, 2005.

Bonadonna, C. and Houghton, B. F.: Grain-size distribution and volume of tephra-fallout deposits, B. Volcanol., 67, 441-456, 2005.

Branca, S. and Del Carlo, P.: Types of eruptions of Etna volcano AD 1670-2003: implications for short-term eruptive behaviour, B. Volcanol., 67, 732-742, 2005.

Bursik, M. I., Carey, S. N., and Sparks, R. S. J.: A gravity current model for the May 18, 1980 Mount-St-Helens plume, Geophys. Res. Lett., 19(16), 1663-1666, 1992a.

Bursik, M. I., Sparks, R. S. J., Gilbert, J. S., and Carey, S. N.: Sedimentation of tephra by volcanic plumes: I. Theory and its comparison with a study of the Fogo A plinian deposit, Sao Miguel (Azores), B. Volcanol., 54, 329-344, 1992b.

Butter, R., Zimanowki, B., and Rodel, H.: Short time electrical effects during volcano eruption, Experiments and field measurements, J. Geophys. Res., 105, 2819-2827, 2000.

Carey, S. N. and Sparks, R. S. J.: Quantitative models of the fallout and dispersal of tephra from volcanic eruption columns, B. Volcanol., 48, 109-125, 1986.

Casadevall, T. J.: Volcanic ash and aviation safety: proceedings of the first international symposium on volcanic ash and aviation safety, US Geological Survey Bulletin, 2047, 1-6, 1994.

Chester, D. K., Duncan, A. M., Guest, J. E., and Kilburn, C. R. J.: Mount Etna, The anatomy of a volcano, Chapman \& Hall, 1985.

Cioni, R., Longo, A., Macedonio, G., Santacroce, R., Sbrana, A., Sulpizio, R., and Andronico, D.: Assessing pyroclastic fall hazard through field data and numerical simulations: Example from Vesuvio, J. Geophys. Res., 108(B2), 2063, doi:10.1029/2001JB000642, 2003.

Connor, C. B., Hill, B. E., Winfrey, B., Franklin, N. M., and La Femina, P. C.: Estimation of volcanic hazards from tephra fallout, Natural Hazards Review, 2(1), 33-42, 2001.

Connor, L. G. and Connor, C. B.: Inversion is the key to dispersion: Understanding eruption dynamics by inverting tephra fallout, in: Statistics in Volcanology, Society for Industrial and Applied Mathematics, Special Publication of IAVCEI No. 1, edited by: Mader, H., Cole, S., and Connor, C. B., Geological Society, London, 231-242, 2006.

Costa, A., Macedonio, G., and Folch, A.: A three dimensional Eulerian model for transport and deposition of volcanic ashes, Earth Planet. Sc. Lett., 241, 634-647, 2006.

D'Amours, R.: Modeling the ETEX plume dispersion with the Canadian emergency response model, Atmos. Environ., 32(24), 4335-4341, 1998.

De Beni, E., Norini, G., and Polacci, M: Aggiornamento dell'attività eruttiva, technical report, available at: www.ct.ingv. it, 2006.

Dubosclard, G., Cordesses, R., Allard, P., Hervier, C., Coltelli, M., and Kornprobst, J.: First testing of a volcano Doppler radar (Voldorad) at Mount Etna, Italy, Geophys. Res. Lett., 26, 33893392, 1999.

Dubosclard, G., Donnadieud, F., Allard, P., Cordesses, R., Hervier,
C., Coltelli, M., Privitera, E., and Kornprobst, J.: Doppler radar sounding of volcanic eruption dynamics at Mount Etna, B. Volcanol., 66, 443-456, 2004.

Folch, A., Cavazzoni, C., Costa, A., and Macedonio, G.: An automatic procedure to forecast tephra fallout, J. Volcanol. Geoth. Res., 177, 767-777, 2008a.

Folch, A., Jorba, O., and Viramonte, J.: Volcanic ash forecast application to the May 2008 Chaitn eruption, Nat. Hazards Earth Syst. Sci., 8, 927-940, 2008b, http://www.nat-hazards-earth-syst-sci.net/8/927/2008/.

Folch, A., Costa, A., and Macedonio, G.: FALL3D: A computational model for transport and deposition of volcanic ash, Comput. Geosci, 35(6), 1334-1342, 2009.

Glaze, L. S. and Self, S.: Ashfall dispersal for the 16 September 1986, eruption of Lascar, Chile, calculated by a turbulentdiffusion model, Geophys. Res. Lett., 18(7), 1237-1240, 1991.

Guffanti, M. and Miller, E. K.: Reducing the threat to aviation from airborne volcanic ash, Proceedings of the 55th Annual International Air Safety Seminar, Dublin, Flight Safety Foundation, Alexandria, VA, 283-293, 4-7 November 2002.

Guffanti, M., Mayberry, G. C., Wunderman R., and Casadevall, T. J.: Effects of volcanic activity on airports, Proceedings of the 2nd International Conference on Volcanic Ash and Aviation Safety, 5, 5-10, 2004.

Guffanti, M., Ewert, J. W., Gallina, G. M., Bluth, G. J. S., and Swanson, G. L.: Volcanic-ash hazard to aviation during the 2003-2004 eruptive activity of Anatahan volcano, Commonwealth of the Northern Mariana Islands, J. Volcanol. Geoth. Res., 146, 241255, 2005.

Harris, D. M., Rose, W. I., Roe, R., and Thompson, M. R.: Radar observations of ash eruptions at Mount St. Helens Volcano, Washington, US Geological Survey Bulletin, 1250, 323-334, 1981.

Heffter, J. L. and Stunder, B. J. B.: Volcanic Ash Forecast Transport and Dispersion (Vaftad) Model, Weather Forecast., 8, 533-541, 1993.

Hort, M. and Seyfried, R.: Volcanic eruption velocities measured with a micro radar, Geophys. Res. Lett., 25, 113-116, 1998.

Horwell, C. J. and Baxter, P. J.: The respiratory health hazards of volcanic ash: a review for volcanic risk mitigation, B. Volcanol., 69, 1-24, 2006.

ICAO: International Civil Aviation Organization: Manual on Volcanic Ash, Radioactive Material and Toxic Chemical Clouds, International Civil Aviation Organization Doc 969, 2004.

Lacasse, C., Karlsdottir, S., Larsen, G., Soosalu, H., Rose, W. I., and Ernst, G. G. J.: Weather radar observations of the Hekla 2000 eruption cloud, Iceland, B. Volcanol., 66, 457-473, 2004.

Leutbecher, M. and Palmer, T. N.: Ensemble forecasting, J. Comput. Phys., 227, 3515-03539, 2008.

Koyaguchi, T. and Ohno, M.: Reconstruction of eruption column dynamics on the basis of grain size of tephra fallout deposits. 1. Methods, J. Geophys. Res., 106, 6499-6512, 2001 a.

Koyaguchi, T. and Ohno, M.: Reconstruction of eruption column dynamics on the basis of grain size of tephra fallout deposits. 2. Application to the Pinatubo 1991 eruption, J. Geophys. Res., 106, 6513-6533, 2001b.

Macedonio, G., Costa, A., and Longo, V.: A computer model for volcanic ash fallout and assessment of subsequent hazard, Comput. Geosci.-UK, 31, 837-845, 2005. 
Macedonio, G., Costa, A., and Folch, A.: Ash fallout scenarios at Vesuvius: numerical simulations and implications for hazard assessment, J. Volcanol. Geoth. Res., 178, 366-377, 2008.

Mather, T. A.: and Harrison, R. G.: Electrification of volcanic plumes, Surv. Geophys., 27, 387-432, 2006.

Miller, T. P. and Casadevall, T. J.: Volcanic ash hazards to aviation, in: Encyclopedia of Volcanoes, edited by: Sigurdsson, H., Houghton, B. F., McNutt, S. R., Rymer, H., Stix, J., Academic Press, San Diego, 915-930, 2000.

Pfeiffer, T., Costa, A., and Macedonio, G.: A model for the numerical simulation of tephra fall deposits, J. Volcanol. Geoth. Res., 140(4), 273-294, 2005.

Prata, A. J. and Grant, I. F.: Retrieval of microphysical and morphological properties of volcanic ash plumes from satellite data: Application to Mt Ruapehu, New Zealand, Q. J. Roy. Meteor. Soc., 127, 2153-2180, 2001.

Prata, A. J. and Kerkmann, J.: Simultaneous retrieval of volcanic ash and SO2 using MSG-SEVIRI measurements, Geophys. Res. Lett., 34, L05813, doi:10.1029/2006GL028691, 2007.

Prodi, F., Tagliavini, A., and Medini, R.: Time variability in rainfall events observed by Pludix, Phys. Chem. Earth Pt. B, 25, 959963, 2000.

Romano, R. and Sturiale, C.: The historical eruptions of Mt. Etna (volcanological data), in: Mount Etna Volcano: A Review of the Recent Earth Sciences Studies, edited by: Romano, R., Mem. Soc. Geol. Ital., 23, 75-97, 1982.

Romano, R., Budetta, G., Caltabiano, T., Condarelli, D., Consoli, O., Lo Giudice, E., Luongo, G., Ricciardi, G., Forgione, G., Gresta, S., Clocchiatti, R., Gillot, P. Y., Kieffer, G., Murray, J. B., Tanguy, J. C., Allard, P., Benhamou, G., Pennisi, M., Bond, A., Decobecq, D., and Kilburn, C.: Etna volcano, Smithsonian Institution, SEAN Bulletin, 11(9), 4-8, 1986.

Romero, R.: The International Airways Volcano Watch (IAVW), Proceedings of 2nd International Conference onVolcanicAsh andAviation Safety, Virginia, USA, 21-24 June 2004.

Rose, W. I., Kostinski, A. B., and Kelley, L.: Real time C band radar observations of 1992 eruption clouds from Crater Peak/Spurr Volcano, Alaska, US Geological Survey Bulletin, 2139, 19-26, 1995.

Salinas, L. J.: Impacts of volcanic ash on airline operations, Proceedings of the 2nd International Conference on Volcanic Ash and Aviation Safety, 1, 11-14, 2004.
Scollo, S., Coltelli, M., Prodi, F., Folegani, M., and Natali, S.: Terminal settling velocity measurements of volcanic ash during the 2002-2003 Etna eruption by an X-band microwave rain gauge disdrometer, Geophys. Res. Lett., 32, L10302, doi:10.1029/2004GL022100, 2005.

Scollo, S.: Fallout Processes of Volcanic Particles from Etna Explosive Eruptions, Ph.D. thesis, University of Bologna, 2006.

Scollo, S., Bonadonna, C., Coltelli M., and Del Carlo, P.: Probabilistic tephra fall-hazard assessment at Etna volcano, Italy, Cities on Volcanoes 4, Quito, Ecuador, 22-27 January 2006.

Scollo, S., Del Carlo, P., and Coltelli, M.: Tephra fallout of 2001 Etna flank eruption: Analysis of the deposit and plume dispersion, J. Volcanol. Geoth. Res., 160, 147-164, 2007.

Scollo, S., Tarantola, S., Bonadonna, C., Coltelli, M., and Saltelli, A.: Sensitivity analysis and uncertainty estimation for tephra dispersal models, J. Geophys. Res., 113, B06202, doi:10.1029/2006JB004864, 2008a.

Scollo, S., Folch, A., and Costa, A.: A parametric and comparative study on different tephra fallout models, J. Volcanol. Geoth. Res., 176, 199-211, 2008b.

Searcy, C., Dean, K., and Stringer, W.: PUFF: A high-resolution volcanic ash tracking model, J. Volcanol. Geoth. Res., 80(1-2), 1-16, 1998.

Spinetti, C. and Buongiorno, M. F.: Volcanic aerosol optical characteristics of Mt. Etna tropospheric plume retrieved by means of airborne multispectral images, J. Atmos. Sol.-Terr. Phy., 69, 981-994, 2007.

Suzuki, T.: A theoretical model for dispersion of tephra, in: Arc Volcanism, Physics and Tectonics, edited by: Shimozuru, D. and Yokoyama, I., Terra Scientific Publishing Company Terrapub, Tokyo, 95-116, 1983.

Vergniolle, S., Brandeis, G., and Mareschal, J. C.: Strombolian explosions, part 2: Eruption dynamics determined from acoustic measurements, J. Geophys. Res., 101, 20449-20466, 1996.

Walker, G. P. L.: Explosive volcanic eruptions - A new scheme of classification, Geol. Rundsch., 62, 431-446, 1973.

Webley, P. and Mastin, L.: Improved prediction and tracking of volcanic ash clouds, J. Volcanol. Geoth. Res., 186(1-2), 1-9, 2009.

Woods, A. W., Holasek, R. E., and Self, S.: Wind-driven dispersal of volcanic ash plumes and its control on the thermal structure of the plume-top, B. Volcanol., 57, 283-292, 1995. 